\title{
Critical review of fossil record of Ranina Lamarck, 1801 (Decapoda, Brachyura, Raninidae), with description of Tethyranina n. gen.
}

\author{
Giovanni Pasini ${ }^{1}$, Alessandro Garassino ${ }^{2 *}$
}

\begin{abstract}
Pasini \& Garassino (2017a) revised the fossil record referred to Ranina Lamarck, 1801 by Karasawa et al. (2014). As result only four species were considered as possible valid species within Ranina: R. palmea E. Sismonda, 1846, R. pellattieroi De Angeli \& Beschin, 2011, R. propinqua Ristori, 1891, and $R$. ranina (Linnaeus, 1758). These species are herein revised and discussed, based on updated observations and critical review of the fossil materials and on a re-definition of the main diagnostic proxy characters sensu Schweitzer (2003) of the type species $R$. ranina (Linnaeus, 1758). This review allows us to establish that $R$. ranina from the middle Pleistocene of Ryukyu Islands (Japan) and R. palmea from the middle Miocene of Italy have consistent proxy characters with the extant Ranina to be considered as valid species within the genus. Moreover, Tethyranina $\mathrm{n}$. gen., with $T$. propinqua (Ristori, 1891) n. comb., is herein proposed to accommodate this questionable fossil species previously assigned to Ranina. Finally R. pellattieroi De Angeli \& Beschin, 2011, lacking the typical characters of Ranina, is considered as a doubtful species within Ranininae.
\end{abstract}

Key words: Raninidae, Ranininae, Ranina ranina, systematics, proxy characters.

Riassunto - Revisione critica delle specie fossili di Ranina Lamarck, 1801 (Decapoda, Brachyura, Raninidae), con la descrizione di Tethyranina $\mathrm{n}$. gen.

Pasini e Garassino (2017a) hanno revisionato le specie fossili attribuite a Ranina Lamarck, 1810 da Karasawa et al. (2014). Il risultato è stato quello di considerare come possibili specie valide riferibili a Ranina solo $R$. palmea E. Sismonda, 1846, R. pellattieroi De Angeli \& Beschin, 2011, $R$. propinqua Ristori, 1891 e $R$. ranina (Linnaeus, 1758). Queste specie sono oggetto di discussione in questa studio sulla base di nuove osservazioni e di una nuova re-definizione dei principali caratteri diagnostici esterni ("proxy characters" sensu Schweitzer, 2003) della specie tipo $R$. ranina (Linnaeus, 1758). Lo studio ha permesso di stabilire che $R$. ranina del Pleistocene medio delle Ryukyu Islands (Giappone) e R. palmea E. Sismonda, 1846 del Miocene medio italiano, presentano consistenti caratteri esterni tipici di Ranina Lamarck, 1810,

\footnotetext{
${ }^{1}$ Via Alessandro Volta 16, 22070 Appiano Gentile (CO), Italia. E-mail: juanaldopasini@tiscali.it

2 Sezione di Paleontologia degli Invertebrati, Museo di Storia Naturale, Corso Venezia 55, 20121 Milano, Italia

*Corresponding author: alessandro.garassino@comune.milano.it; alegarassino@gmail.com
}

(C) 2018 Giovanni Pasini, Alessandro Garassino

Received: 31 August 2017

Accepted for publication: 22 December 2017 e sono quindi considerate come specie valide all'interno del genere. Inoltre si propone Tethyranina $n$. gen., con T. propinqua (Ristori, 1891) n. comb., specie precedentemente attribuita a Ranina. Infine, $R$. pellattieroi De Angeli \& Beschin, 2011, non presentando i caratteri tipici di Ranina é considerata specie dubia nella sottofamiglia Ranininae.

Parole chiave: Raninidae, Ranininae, Ranina ranina, sistematica, caratteri diagnostici esterni.

\section{INTRODUCTION}

Recently Pasini \& Garassino (2017a) gave a preliminary review of the 23 fossil species previously referred to Ranina by Karasawa et al. (2014). As result, three species were assigned to Lophoranina Fabiani, 1910, one species to Calappa Weber, 1795, one was considered a doubtful species within Decapoda, four specimens were considered as Ranina nomina dubia, and twelve were considered doubtful species within the genus. Later, Pasini \& Garassino (2017b) revised two species, previously assigned to Ranina, assigned them to Alcespina Pasini \& Garassino, 2017. Based upon these reviews, only four species were considered as possible valid species within Ranina, as follows: R. palmea E. Sismonda, 1846, R. pellattieroi De Angeli \& Beschin, 2011, R. propinqua Ristori, 1891, and $R$. ranina (Linnaeus, 1758).

These species are herein discussed, based on updated observations, critical review of fossil species, and re-definition of the main diagnostic proxy characters sensu Schweitzer (2003) of the type species, Ranina ranina (Linnaeus, 1758), also supported by the direct observation of a large sample of different sized taxidermy-preserved specimens of both sex from the Pacific area (Pasini pers. obs., 2015-2017) and the most recent observations on the extant specimens of the type species by Luque (pers. comm., 2017).

\section{EXTERNAL MORPHOLOGIC CHARACTERS (PROXY CHARACTERS) OF RANINA}

The fossil specimens tentatively assigned to Ranina Lamarck, 1801, are still very scarce (Pasini \& Garassino, 2017a), including mostly incomplete or badly preserved specimens, with the ambulatory legs and pleonal parts that are often scarcely preserved, and therefore, not useful in morphological comparisons. Moreover the absence of 
a clear definition for the diagnostic external morphologic characters [proxy characters sensu Schweitzer (2003)] of the type species (Ranina ranina) has resulted not clearly defined characters for fossil specimens (Guinot pers. comm., 2014; Luque pers. comm., 2016). The most recent diagnosis for Ranina was proposed by Karasawa et al. (2014: 45), based on the extant $R$. ranina, reporting the anterolateral spines as "... bifid or trifid". This assumption, however, results unclear as checked by direct observations on the shape of anterolateral spines in many extant specimens in which both spines result to be trifid (Pasini pers. obs., 2015-2017), as confirmed also by Nyborg (pers. comm., 2016). According to Luque (pers. comm., 2017), "There might be some intraspecific variability in extant R. ranina, and occasionally a specimen can display a trifid spine in one side, but bifid in the other side. This seems to be an exception to the 'trifid' rule, but I would confidently say that, at least as for extant R. ranina goes, both anterolateral spines in mature males and females are consistently trifid".

Moreover, Matondo Dulce-Amor \& Demayo (2015: 253) gave a description of the external morphological characters, describing the orbito-frontal and latero-anterior margin of the extant $R$. ranina from Philippines as having a "trifid fronto-lateral lobe (= first anterolateral spine)" and "anterolateral (margin) has a trifid lobe... (= second anterolteral spine)", beside "... however, in smaller, younger individuals, carapace variation is inconspicuous", and "this observation agreed with that of Uchida", based on the extant $R$. ranina from the Hawaiian Islands area by Uchida (1986). Recently Emmerson (2016: 258) also clearly described the extant $R$. ranina from the western Indian Ocean as having "...; two trifid processes on the anterolateral corner of carapace, ...", supporting our observations on the anterolateral spine shape in $R$. ranina.

The trifid anterolateral spines is an important character that once combined with the triangular rostrum, the direction of the anterolateral spines, the shape of the postorbital spine, and the dorsal ornamentation, represents a mix of peculiar distinctive proxy characters almost distinguishing Ranina from the other species of the genus.

In this study we tentatively follow a selected combination of these diagnostic proxy characters based (in part) on the more recent diagnosis for the genus by Karasawa et al. (2014), pointing out that, both anterolateral spines in extant Ranina are trifid (not "bifid and trifid" as reported by Karasawa et al., 2014: 54), adding substantial morphological observations on the shape of the postorbital spine and arrangement of each of the anterolateral spines (see following discussion in this paper).

\section{Abbreviations}

lcxp: carapace length; MCZ: Museo civico "G. Zannato", Montecchio Maggiore, Vicenza (Italy); MFM: Mizunami Fossil Musem, Mizunami (Japan); MPUR: Museo Geologico Università "La Sapienza", Roma (Italy); MSNM: Museo di Storia Naturale di Milano, Milano (Italy); MUSNAF: Museo di Storia Naturale dell'Accademia dei Fisiocritici, Siena (Italy); s1-s6: pleonal somites 1 to 6; wcxp: carapace width.

\section{SYSTEMATIC PALAEONTOLOGY}

Infraorder Brachyura Latreille, 1802

Section Raninoida Ahyong, Lai, Sharkey, Colgan \& Ng, 2007

Superfamily Raninoidea De Haan, 1839

Family Raninidae De Haan, 1839

Subfamily Ranininae De Haan, 1839

\section{Included genera}

Alcespina Pasini \& Garassino, 2017; Lophoranina Fabiani, 1910; Ranina Lamarck, 1801; Raninella A. Milne Edwards, 1862; Remyranina Schweitzer \& Feldmann, 2010; Tethyranina n. gen. (this study); Vegaranina Van Bakel et al. 2012.

\section{Genus Ranina Lamarck, 1801 (Fig. 1)}

Ranina Lamarck, 1801: 156.

Hela von Münster, 1840: 24.

Palaeonotopus Brocchi, 1877: 6.

Ranina - De Haan 1839: 137. - Poore 2004: 322. - Karasawa et al. 2014: 45.

Diagnosis by Karasawa et al. (2014): Carapace generally widest in anterior one quarter, narrowing posteriorly; rostrum trifid, with axial two spines serving as inner orbital spines, central spine triangular; intra- and outer orbital spines triangular; anterolateral margin generally with two spines that are bifid or trifid, often larger and more complexly ornamented in males; postfrontal region depressed slightly below level of remainder of carapace, can be granular or scabrous; remainder of carapace ornamented with forward directed spines; appendages and pterygstome ornamented with less densely-spaced spines; sternum smooth.

Remarks: The diagnosis of Ranina is based on the characters of the extant type species $R$. ranina.

The systematics adopted in this study follows partially the recent diagnosis for the genus proposed by Karasawa et al. (2014: 45), but pointing out that the first and second anterolateral spines are trifid in both sexes, also in juvenile stages, and never bifid as previously reported by some authors (Sakai, 1937; Poore, 2004; Karasawa et al. 2014). Moreover, we add herein some others useful proxy generic characters to the diagnosis by Karasawa et. al. (2014), as follows:

- the postorbital spine shape, divided distally into two spines, is forked (= bifid), with the outer spine shorter than the inner; however, as pointed out by Luque (pers. comm., 2017) "some small specimens seem to have not just bifid but multi-spinose outer orbital/postorbital spines; this clearly seems to change during ontogeny, and those additional small spines become obsolete and disappear".

- the first anterolateral spine, slightly inclined outward and the second anterolateral spine more inclined at about a 45-degree angle to the carapace longitudinal median axis, never strongly forward or outward directed; however, as pointed out by Luque (pers. comm., 2017) "this seems to change quite a bit among populations (of extant R. ra- 


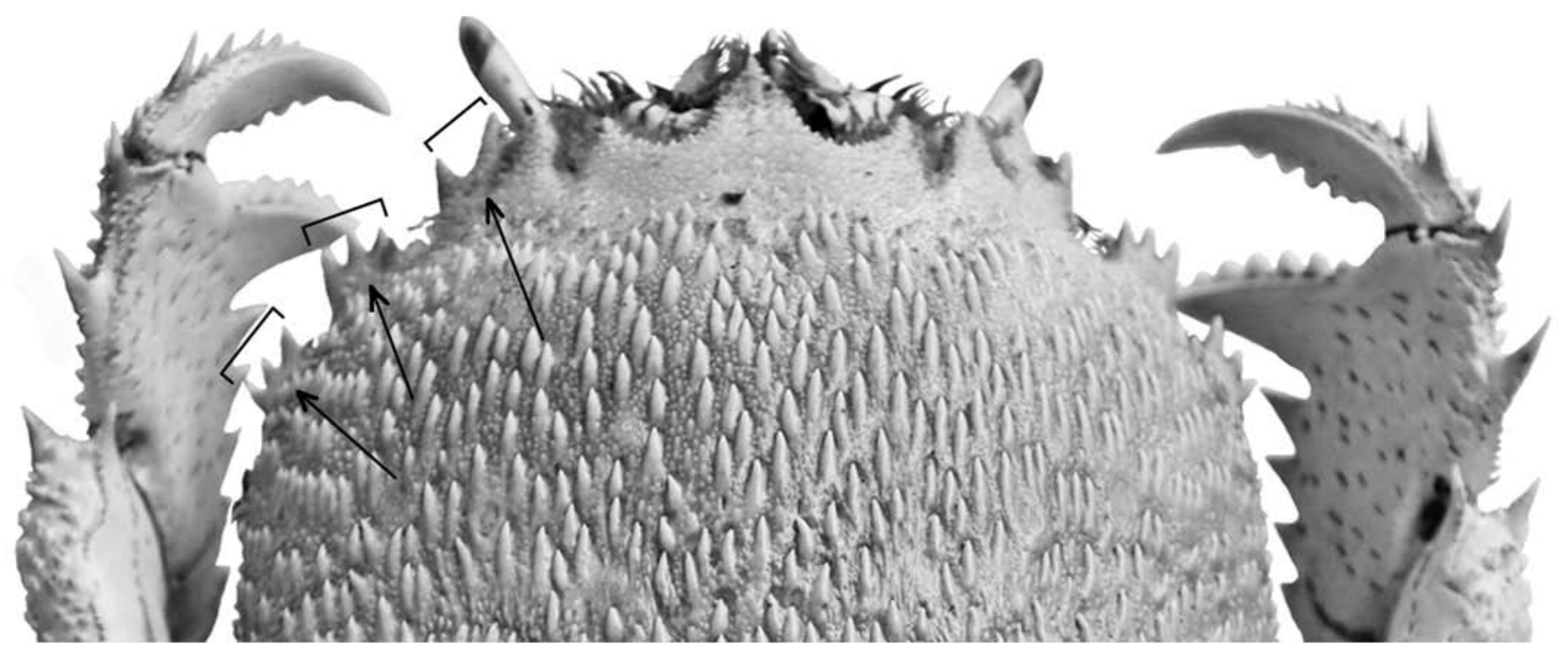

Fig. 1 - Ranina ranina (Linnaeus, 1758), MSNM Cr 2442, extant adult female, Western Indo-Pacific Ocean. Orbitofrontal outline with the main diagnostic proxy characters.

nina); some tend to have closely spaced spines directed forwards, whereas others have a wider spaced spines and inclined at more pronounced angles". We were unable, however, to consider in the fossil record these variations due to the scarcity of specimens.

The combination of these unambiguous additional morphological characters are also adopted in this study to distinguish Ranina from others fossil genera within Ranininae.

Type species: Cancer raninus Linnaeus, 1758, subsequent designation by Latreille (1810).

Stratigraphic range: middle Miocene - middle Pleistocene and extant.

Including fossil species: Ranina palmea $\mathrm{E}$. Sismonda, 1846; $R$. ranina (Linnaeus, 1758).

Paleogeographic distribution: Mediterranean area (exclusively fossil) - Indo-Racific area (fossil and extant).

Emended diagnosis (present study): Carapace subovoid, wider anteriorly; dorsal ornamentation, with sparse granular-spiny tubercles directed forward, never ranging into tegulate rims; triangular rostrum; postorbital spine bifid, forked, with the outer spine shorter than the inner in adult extant species [small specimens (immaturejuveniles) seem to have not just bifid but multi-spinose outer orbital-postorbital spines, whereas in some large sized specimens the secondary spine can be much developed than the outer-postorbital spine (Luque pers. comm., 2017)]; first and second anterolateral spines always trifid, often larger and more complexly ornamented in males; first one slightly inclined outward with the second diverging usually at but not more than a 45-degree angle to the carapace longitudinal median axis, more complexly ornamented and developed in adult males. Large, flat chelae with transverse dactylus; dactylus bearing 7 spines on the upper margin and pointed tip downward directed; propodus flat, lined with tubercles; propodus with 2 prominent dorsal spines and 5 prominent spines on the lower margin; elongate carpus with 2 parallel spine on the anterior upper margin pointing outward in opposite direction; merus with a single spine on the upper anterior margin. Appendages and pterygstome ornamented with less densely-spaced spines; sternum shield smooth, s1-s3 fused, s4 broad at the anterior margin, convex and lateral margin concave; s5 with shallow longitudinal depression.

\section{Ranina palmea E. Sismonda, 1846 (Fig. 2)}

Ranina palmea E. Sismonda, 1846: 64, Pl. 3, figs. 3, 4. Ranina palmea - Reuss 1859: 21. - Crema 1895: 672, Pl. 3, figs. 12a-e. - A. Milne Edwards 1872: 4, 9. - Fabiani 1910: 9. - Glaessner 1929: 362. - De Angeli et al. 2009: 120, 121. - De Angeli \& Beschin 2011: 13, 15. - Van Bakel et al. 2012: 209. - Karasawa et al. 2014: 260.

Hela palmea - Lörenthey in Lörenthey \& Beurlen 1929: 109.

Diagnosis: Sismonda (1846) only provided a limited morphological description and comparisons (in Italian language).

Type material: Reale Museo Geologico di Torino, today lost (Ormezzano pers. comm., 2014).

Type locality: Torino Hill sandstone (Piedmont, northwestern Italy).

Geological age: Neogene (middle Miocene, "Helvetian"- now Serravallian).

Examined material: Line drawings proposed by Sismonda (1846: Pl. 3, figs. 3, 4) and later by Crema (1895: Pl. 3, figs. 12a-e).

Description: We provide herein a literal translation of the original description by the author, wrote in old Italian language and never previously translated, to facilitate comparisons and discussion of this lost species.

Literal translation: “... The specimen consists of a big sized crustacean, having maximum transversal diameter of 0,077 (meters), longitudinal of 0,083 (meters), ab- 


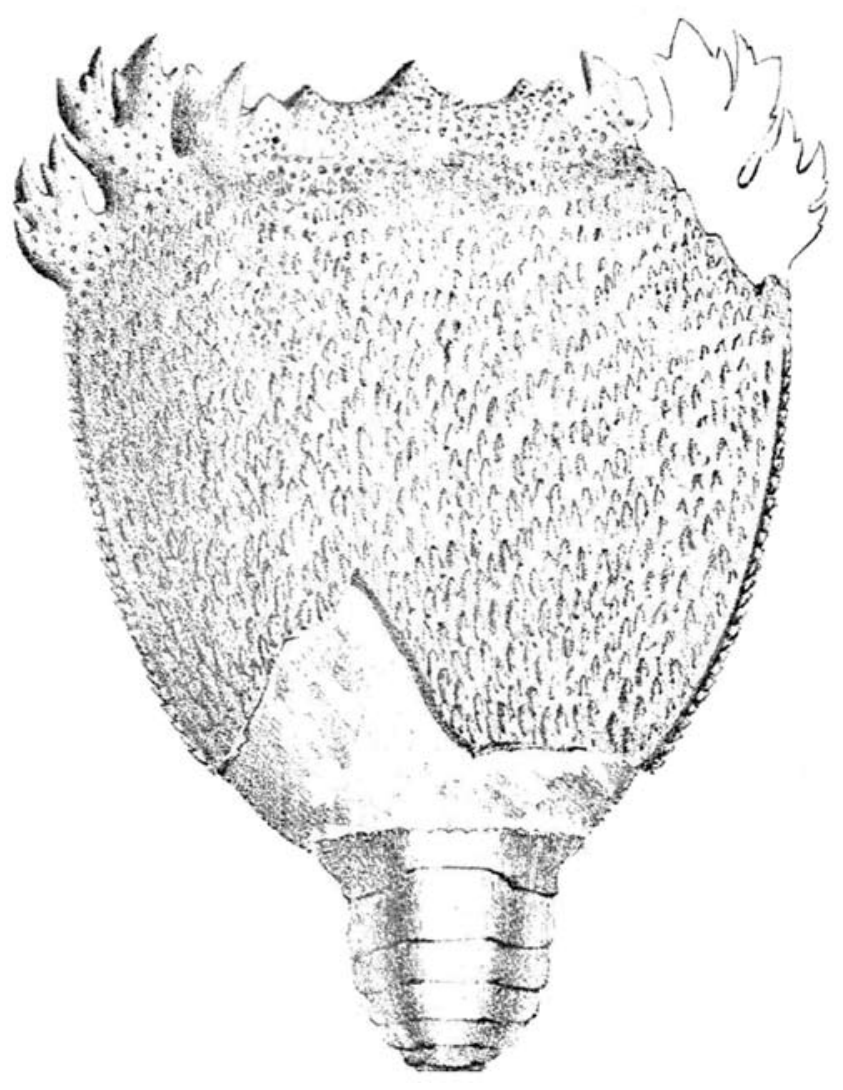

Fig. 2 - Ranina palmea E. Sismonda, 1846, original line drawing by the author (Sismonda, 1846: Pl. 3, fig. 3).

domen excluded. (The carapace) has a triangular shield leaning to an ovate shape, convex dorsally and with thousands of small tubercles or spines fairly elongated, flattened, forward directed, bigger toward the abdomen, worsen to thinner tubercles on the frontal region. Upper, or frontal margin concave, divided in nine lobes, of which the outermost are separated each other by deep furrows. The central lobe is scarcely projected, originating a triangular rostrum, strengthen at each side by a fairly acute tooth; this tooth is shorter than the others (teeth), giving the front concave, a distinctive character of the male individuals, as observed by Milne-Edwards (instead) the female front is arcuate and convex; and anymore, in added to the sexual differences, according to De Haan, that the upper margin of the palms of the Ranina males are armed by obtuse spines, while the spines are acute in females. The lobes nearby the median (mytoyens internes) end in a single tooth; the following (lobes) (mitoyens externes) are wide, flattened, and ending with two teeth, each splitting in other ones smaller, a detail not well represented in the drawing (= Pl. 3, fig. 3); finally the more external frontal lobes, the last and second last, are the more developed, flattened, wide, ending in three points or triangular teeth, they also bears smaller pointed spines here and there along the margins of the main tips of the anterolateral spines, and this is the main difference among the described specimen and the Ranina Dentata by Latreille $[=R$. ranina (Linnaeus, 1758)]. Lateral margins convex, shaw-like rimmed, abdomen narrow, trian- gular, elongate, slightly down-turned, with seven dorsally carinate rings, having convex anterior margin, concave posteriorly. The sternum and maxilliped are covered by an hardened sandstone... . Walking legs poorly preserved. The left distal thoracic cheliped (fig. 4) is the only more or less preserved, limited to the carpus and manus that is very flattened, both are covered by rather higth and protruded small tubercles; the upper margins bears two large spines, moreover the lower margin of the fixed finger has five teeth, the dactylus, flattened, curved also bears some teeth along the margins. Fossil in the Miocene sandstone from the Torino hill.".

Discussion. Since the type material is lost, the discussion is simply based on the original description by Sismonda (1846) and observations on the line drawings proposed by Sismonda (1846: Pl. 3, figs. 3, 4) and later by Crema (1895: Pl. 3, figs. 12a-e).

Crema (1895: 672) added some observations to the description by Sismonda (1846), and proposed a re-drawing of the species under direct observation: "(I) Refigure the right chela (fig. 12c) and propose a schematic representation of the anterior lateral side (fig. 12a) of the specimen, due that the original figures reported to date contains several inaccuracy" (literal translation). Moreover the author reported "(I) examined also several carapace fragments and the dorsal shield of a young specimen...". The fossil site of the additional material is not clearly specified in the description by Crema, but the author reported at the end of his notes "Elveziano: Colli Torinesi, Sciolze. Bardassano [Elvezian (Serravalian); Torino Hills, Sciolze. Bardassano - Piemont. northwestern Italy]", that is not the type locality of the Sismonda's specimen. Crema (1895: 672, 673) pointed out that the dorsal ornamentation "... specially in the anterior and median parts shows other smaller tubercles among the spiny tubercles, less marked than in the living species (= R. ranina)..."; that " the abdomen is very different from the ideal reconstruction proposed by Sismonda, shows the first five segments well preserved, but lacks of the telson; is perfectly close to this of R. serrata (= R. ranina)" (Pl. 3, fig. 12b); and moreover that “... the left chela is about 1/3 bigger than the right...(Pl. 3, fig. 12c), and that "The parts observables of the walking legs are close to the of the R. serrata"(Pl. 3, fig. 12e).

Ranina palmea shows all the typical proxy characters of the genus, such as: carapace subovate, convex dorsally, ornate by forward pointed spines or tubercles forward directed, smaller on the frontal region; rostrum triangular with two nearly acute spines at the wide bottom; anterolateral spines flattened and wide, trifid, the first one wider; the second one more inclined at a less than a 45-degree angle to the carapace longitudinal median axis, and in having same shape and ornamentation on the flattened spiny chela and elongate carpus; serrate anterolateral margin, convex; long serrate posterolateral margin, narrowing posteriorly, posterior margin straight; elongate, triangular pleon, smooth, with somites dorsally inflated longitudinally, convex anteriorly and nearly concave posteriorly; flattened, tuberculate chela with two wide dorsal spines forward directed; curved dactylus, flattened, with dentate dorsal margin; flattened fixed finger, occlusal margin with five rounded teeth. 
Moreover, based upon the body size (lcxp: $83 \mathrm{~mm}$; wcxp: $77 \mathrm{~mm}$ ) and presence of well-developed anterolateral spines, according to Sismonda (1846), the specimens might belong to an adult (mature) male, in the hypothesis that also the fossil mature representatives of Ranina had a notable sexual difference in the shape of the anterolateral spines, as in the extant type species.

An hypothesis for the female and male growth-reproductive patterns (= adult stages) of the extant $R$. ranina is given for instance by the model proposed by Minagawa (1993: 2029, fig. 8), and also inferable to the different stages of growth of carapaces figured by Sakai (1937: 179, text-fig. 45), whereas according to Nyborg (pers. comm., 2016), the juvenile stage drawing proposed by Sakai (1937) is incorrect at level of the anterolateral spine (figured as bifid and trifid), whereas both are always trifid.

According to Sismonda (1846: 65) and Crema (1895: 672 ), the specimen has a general carapace shape and dorsal ornamentation close to those of the adult males of ex$\tan t R$. ranina. Indeed, Sismonda (1846: 65), pointed out that the "major difference among the fossil described (= Ranina palmea) and the $R$. dentata by Latreille $[=R$. ranina (Linnaeus, 1758)]", consist in the presence on "...the more external lobes of the front, the last and second one are the more developed, flattened, wide, ending in three points or triangular teeth, then also bearing smaller poin- ted spines here and there along the margins of the main tips of the anterolateral spines ...".

The relative shortness of the frontal spines, the shorter wider triangular rostrum, the more serrate, spiny postorbital bifid spine, and the presence of accessorial sparse spines along both anterolateral spines are characters that can justify the specific assignment to $R$. palmea .

In conclusion we can consider $R$. palmea as a valid species within Ranina, representing the oldest fossil species known for the genus. The presence of Ranina in the paleoMediterranean almost since the middle Miocene is very intriguing, opening a new look to the possible origins for the genus, joined to some paleo-geographic problematics.

\section{Ranina ranina (Linnaeus, 1758) (Fig. 3A, B)}

Cancer raninus Linnaeus, 1758: 625 (as Cancer raninus), subsequent designation by Latreille (1810).

Ranina ranina - Oshiro \& Sakida 1980, Pl. 2, fig.9. - Karasawa 1997: 39, Pl. 7, fig. 1. - Karasawa 2000: 173, Tab. 1, Pl. 2, fig. 9. - Schweitzer et al. 2010: 74. - De Angeli \& Beschin 2011: 13. - Van Bakel et al. 2012: 209. - Karasawa et al. 2014: 260. - Pasini \& Garassino 2015: 51. - Famiani et al. 2015: 344 (synonymies just for the fossil species).
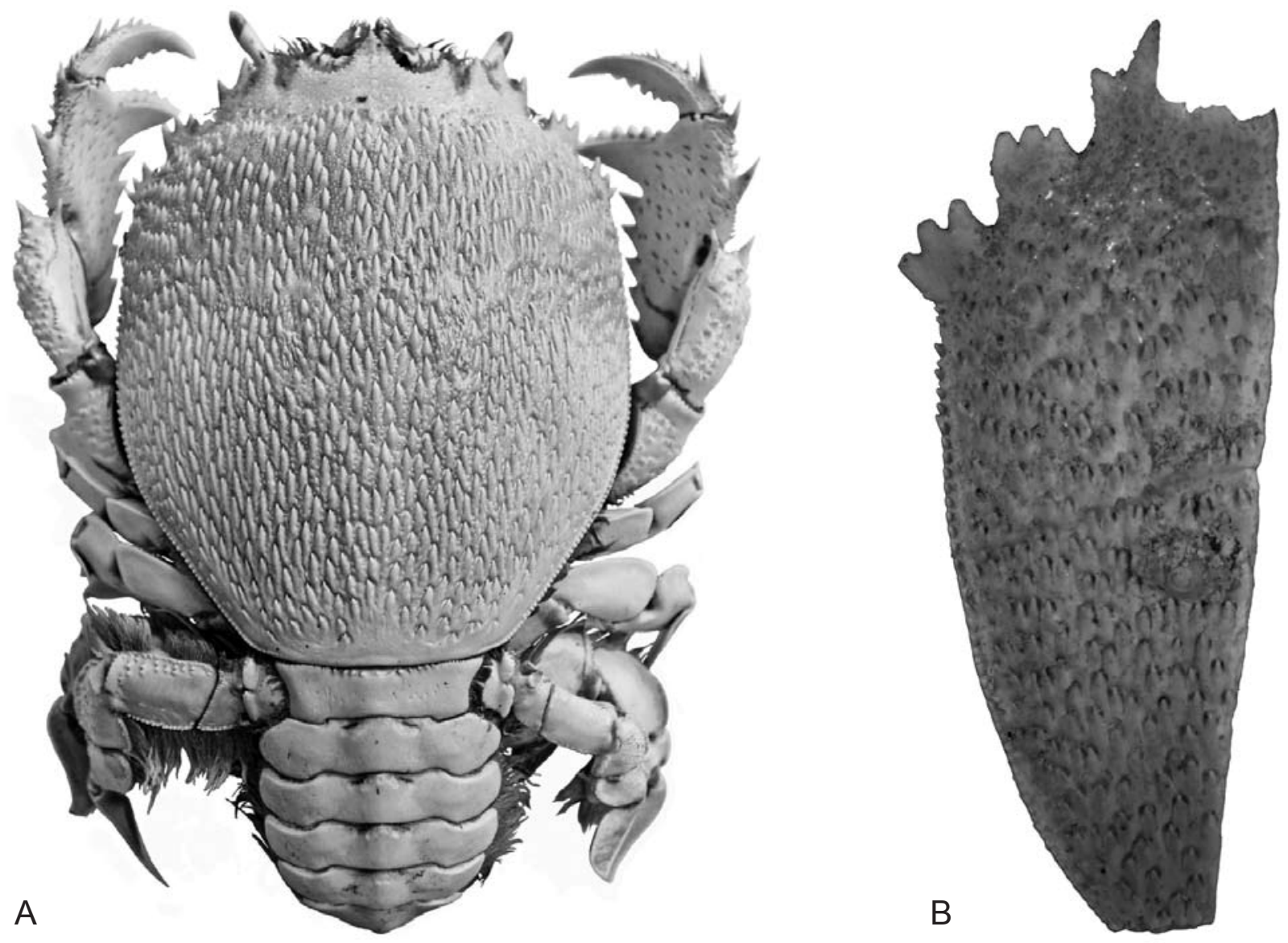

Fig. 3 - A) Ranina ranina (Linnaeus, 1758), MSNM Cr 2442, extant adult female, Western Indo-Pacific Ocean. (x 0.8). B) Ranina ranina (Linnaeus, 1758), WN-1, MFM 142326; Ryukyu Islands, Japan (x 2.5). 
Diagnosis: as for the genus.

Locality: Ryukyu Group of Okinawa-jima (Ryukyu Islands, Japan).

Geological age: Naha Formation (middle Pleistocene) - Recent.

Examined material: One specimen (WN-1, MFM 142326), original picture.

Description: Carapace incomplete, broken longitudinally, with serrate margins; widest at anterior one-quarter, narrowing posteriorly; rostrum not preserved; intra- and outer orbital spines pointed, triangular; postorbital spine divided into two spines (= bifid), with the inner spine longer; anterolateral margin with two trifid spines forward directed, the second one more inclined at about 45-degree angle to the carapace longitudinal median axis; post-frontal region slightly depressed (as preserved) below level of remainder of carapace scabrous; remainder of carapace ornamented with forward directed inclined sparse spines, sometime aligned in groups of 4-6 on the central part of the carapace.

Discussion. Oshiro \& Sakida (1980) reported R. rani$n a$ from the Pleistocene of the Ryukyu Islands (Japan) (Pl. 2, fig. 9 in Karasawa, 2000) the only fossil report for the extant species. Though incomplete, the specimen shows the main characters of the carapace of the type species $R$. ranina in having: a carapace widest at the anterior onequarter, narrowing posteriorly; a bifid postorbital spine; an anterolateral margin with both two spines that are trifid and forward directed, the second one more inclined at about a 45-degree angle to the carapace longitudinal median axis; a post-frontal region depressed slightly below level of remainder of carapace, with sparse nodes; and the remainder of carapace ornamentation not uniform, with sparse forward directed inclined spines.

\section{Genus Tethyranina nov.}

Diagnosis: Carapace ovate, tapering posteriorly; wide fronto-orbital margin convex; dorsal surface with triangular tubercles-spines randomly arranged; pointed triangular rostrum; triangular orbital spine; subtriangular supraorbital spine flattened, forward directed with slightly undulate, convex outer lateral margin, followed by two wide, flat anterolateral spines slightly projected; first anterolateral spine bifid, slightly oblique to the middle longitudinal axis; second anterolateral spine trifid, outward directed, forming an angle about 45-degrees to the carapace middle line.

Type species: Tethyranina propinqua (Ristori, 1891) n. comb.

Fossil species: T. propinqua (Ristori, 1891) n. comb.

Etymology: Alluding to the palaeogeographic distribution (Tethys Ocean) and the closer raninid genus, $R a$ nina.

Geological range: early Miocene - early Pleistocene.

Palaeogeographic distribution: The genus appears to be, from the current knowledge of the fossil record, restricted to the paleo-Mediterranean area.

Discussion. We justify the description of the new genus in having a unique combination of substantial dis- tinctive characters within the Ranininae, such as the triangular rostrum, postorbital spine subtriangular flattened, forward directed, with slightly undulate, convex outer lateral margin; first anterolateral spine bifid, and second anterolateral spine trifid, outward directed, forming an angle about 45 -degrees to the carapace middle line. The chelipeds are poorly known, as reported by Pasini, Garassino \& De Angeli in Baldanza et al. (2014: 274), but appear similar in ornamentation and shape to those of $R$. ranina.

Tethyranina $\mathrm{n}$. gen differs from the others Ranininae genera as follows:

- Alcespina Pasini \& Garassino. 2017, has trifid pointed rostrum; first anterolateral spine bifid, forward directed, parallel to the middle longitudinal axis; second wide anterolateral spine pointed, flat, nearly straight anterior margin, strongly outward projected, forming an angle more than $75^{\circ}$ (usually about $90^{\circ}$ ) to carapace middle line, with triangular unequal serrate spines (3-4) on the anterior edge.

- Lophoranina Fabiani, 1910, has typical carapace surface with typical transverse terraces, usually parallel to one another, two bifid anterolateral spines, broad sternum with C-shaped concave lateral margins.

- Lophoraninella Glaessner, 1936, has carapace with short scabrous ornamentation in anterior third, serrate transverse rimmed ornamentation on remainder carapace.

- Ranina Lamarck, 1801, has sub-ovate convex carapace with wider surface covered by densely spaced inclined nodes; a single triangular rostrum tip; smaller orbital spines, postorbital spine bifid, forked with inner spine shorter than the inner; two anterolateral palmate trifid spines, first slightly anterolaterally directed, the second diverging at about a 45 -degree angle to the carapace longitudinal median axis.

- Raninella A. Milne Edwards, 1862, has carapace widest about half the distance posteriorly, carapace surface covered by densely spaced inclined nodes, anterolateral margin generally with two flattened spines triangular or more narrow, sternum lanceolate distally, narrow anteriorly and wider at level of the last posterior sternites.

- Remyranina Schweitzer \& Feldmann, 2010, has expanded, moderately broad antero-lateral margin, ovoid carapace slightly larger than wide, and carapace ornamentation granular on anterior half and strongly terraced in posterior half widest about half the distance posteriorly on carapace, anterolateral margins appearing to have two projections, carapace ornamentation granular in anterior half and strongly terraced in posterior half.

- Vegaranina Van Bakel, Guinot, Artal, Fraaije \& Jagt, 2012 , has anterolateral margin with three triangular spines, carapace ornamented with developed broadly spaced transverse terraces.

Note. Tethyranina $\mathrm{n}$. gen. seems to include fossil taxa only from the paleo-Mediterranean area. Indeed we cannot exclude that some of the European species (too poorly preserved for a certain assignment) and still considered doubtfully ?Ranina (see Pasini \& Garassino, 2017a) could also represent different taxa within this genus (see: ?Ranina brevispina, ?R. haszlinskyi, and perhaps ?R. granulata). 
Tethyranina propinqua (Ristori, 1891) n. comb. (Fig. 4A, B)

Ranina propinqua Ristori, 1891: 11-14, Pl. 1, figs. 4-7 (illustrated as mirrored).

Ranina propinqua - Lőrenthey 1898: 137. - Fabiani 1910: 9. - Glaessner 1929: 363. - De Angeli \& Garassino 2006: 38. - Manni 2006: 108, fig. 38. - De Angeli et al. 2009: 120, 121. - Schweitzer et al. 2010: 74. - Pasini \& Garassino 2010: 116. - De Angeli \& Beschin 2011: 13, 15, 17. - Van Bakel et al. 2012: 209. - Pasini, Garassino \& De Angeli in Baldanza et al. 2014: 274, 276, fig. 6A-E2. - Garassino et al. 2014: 122, fig. 1F. - Karasawa et al. 2014: 260. - Famiani et al. 2015: 342-344, fig. 4A-D.

Hela propinqua - Lörenthey in Lörenthey \& Beurlen 1929: 109.

Diagnosis: as for the genus.

Type material: MPUR i.543.

Type locality: Città della Pieve (Perugia, Umbria, central Italy).

Type age: early Pleistocene (Gelasian-Calabrian).

Examined material: Holotype and three additional specimens: MUSNAF 7075, from the early Pleistocene of Fabro Scalo (Terni, Umbria); MSNM i28012, from the early Pleistocene of Orzalume-Cottano (Orvieto, Umbria); MSNM i2787, from late Pleistocene Trumbacà (Reggio Calabria, Calabria).

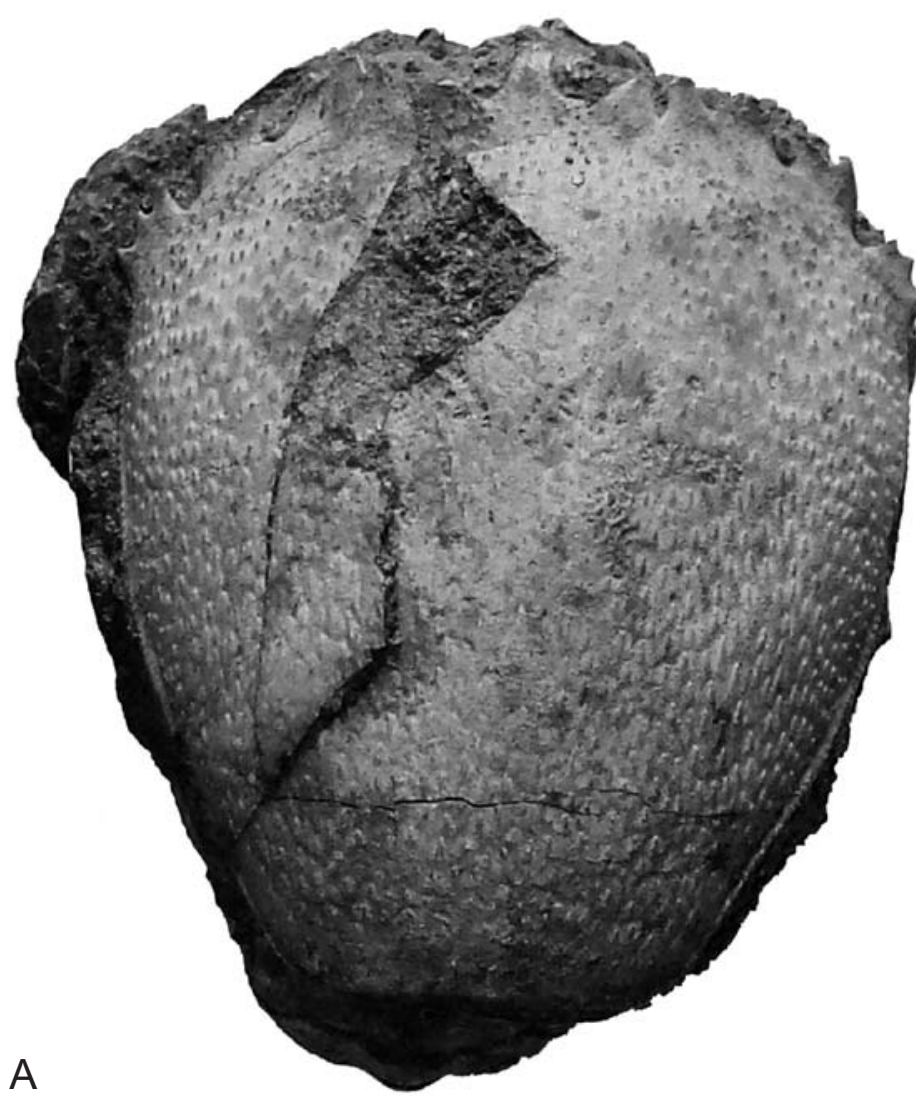

Description (see Pasini, Garassino \& De Angeli in Baldanza et al., 2014).

Discussion. Ristori (1891) described $R$. propinqua based on a sole well-preserved female specimen from Città della Pieve (Perugia, Umbria, Italy). Later, Pasini, Garassino \& De Angeli in Baldanza et al. (2014) and Famiani et al. (2015) reported additional specimens of this species from Fabro Scalo (Terni, Umbria, Italy) and OrzalumeCottano (Orvieto, Umbria, Italy), revising this poorly known species. Moreover, Bizzarri \& Baldanza (2009) attested that the fossiliferous area reported by Ristori (1891) has to be referred to early Pleistocene (GelasianCalabrian). Garassino et al. (2014: 122, fig 1F) reported also $R$. propinqua from the late Pleistocene of Trumbacà (Reggio Calabria, southern Italy).

All the specimens reported cannot be assigned to $R a$ nina since they lack the distinctive characters for the genus, whereas the combination of the triangular rostrum with anterolateral spines respectively bifid and trifid are typical of Tethyranina $\mathrm{n}$. gen. to which the specimens are assigned.

\section{Doubtful species assigned to Ranina}

\section{?Ranina pellattieroi De Angeli \& Beschin, 2011 (Fig. 5)}

Ranina pellattieroi De Angeli \& Beschin, 2011: 15-17, fig. 3, Tab. 1.

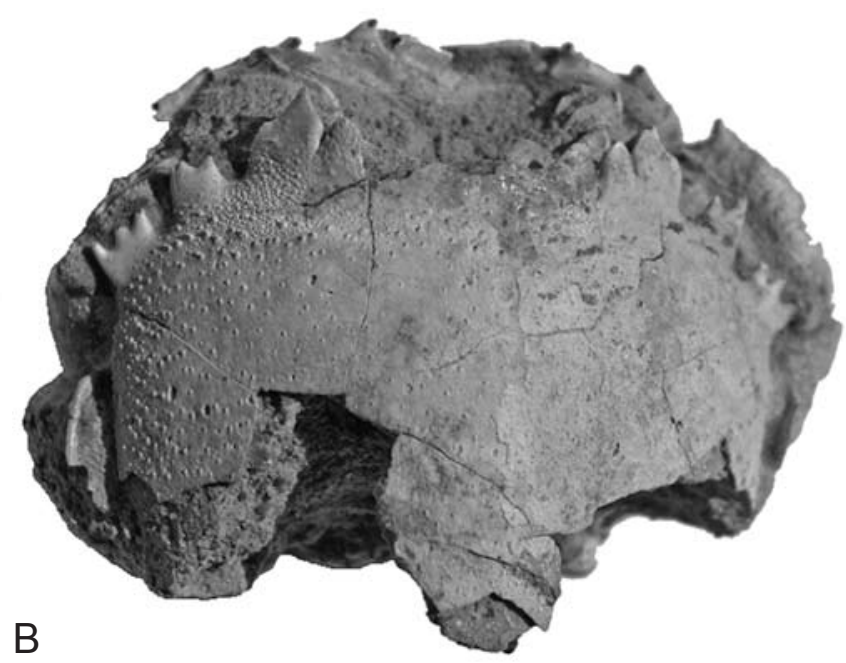

Fig. 4 - A) Tethiranina propinqua (Ristori, 1891) n. comb., Holotype MPUR i.543, dorsal view. B) Tethiranina propinqua (Ristori, 1891) n. comb., Paratype MUSNAF 7075. (x 1.5). 
Ranina pellattieroi - Karasawa et al. 2014: 260. - Pasini, Garassino \& De Angeli in Baldanza et al. 2014: 276, fig. 8D. - Famiani et al. 2015: 344.

Diagnosis by De Angeli \& Beschin (2011): Carapace slightly convex, longer than wide; triangular orbital spine, subtriangular supraorbital spine forward directed with outer slighttly undulate, convex lateral margin; anterolateral margin short, with two spines; first anterolateral spine flat, forward directed; second anterolateral spine outward directed, with three needle-like small spines on distal margin; posterolateral margin long and rimmed; weak branchiocardiac groove; frontal area, orbital teeth, and anterolateral teeth with small granulations; hepatic and postfrontal regions with tubercles; median and posterior portion of the carapace with spiny tubercles arranged in small groups.

Type material: MCZ 3392-I.G.336930.

Type locality: Monte Crocetta di Creazzo quarry (Vicenza, N Italy).

Type age: early Miocene.

Examined material: Holotype.

Description: see De Angeli \& Beschin (2011).

Discussion. The holotype shows only some generic morphological affinities with Ranina, but it cannot be assigned to this genus because in Ranina both anterolateral spines are trifid and in $R$. pellattieroi the first anterolateral spine is bifid and second is trifid. The frontal margin is incomplete, lacking the rostrum that is an important diagnostic character in Ranina, whereas the combination of

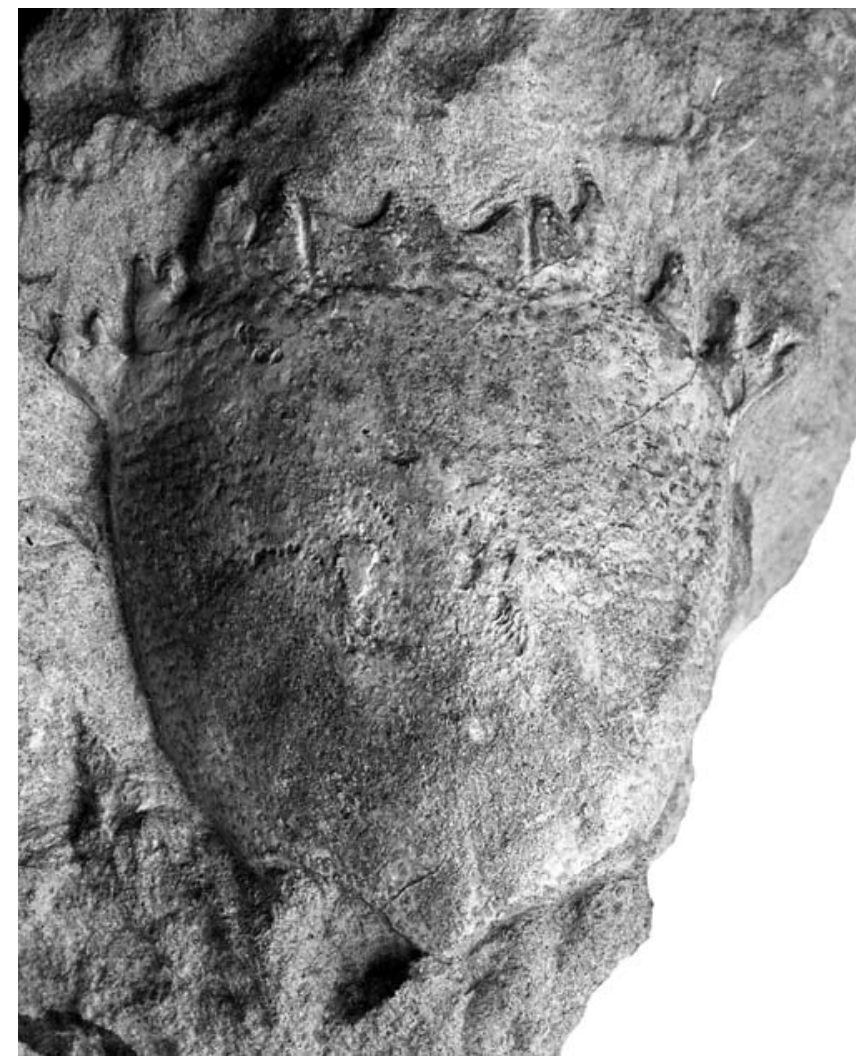

Fig. 5 - ?Ranina pellattieroi De Angeli \& Beschin, 2011, Holotype MCZ 3392-I.G.336930, dorsal view (x 1.5). three proxy characters, such as the subtriangular postorbital spine, first anterolateral spine bifid and second one trifid more outward projected, fit in some way those of Tethyranina $\mathrm{n}$. gen. However, the shape of the anterolateral spines more elongated and slender and the peculiar ornamentation of the dorsal carapace with "median and posterior part of the carapace with spiny tubercles arranged in small groups" (De Angeli \& Beschin, 2011: 15 ) distinguish $R$. pellattieroi from Tethyranina $\mathrm{n}$. gen. In conclusion, $R$. pellattieroi is herein considered a doubtful species within Ranininae.

\section{CONCLUSIONS}

This revision allows us to establish that:

- Ranina ranina from the middle Pleistocene of western Pacific (Japan) and R. palmea from the Miocene of the paleo- Mediterranean Sea, are the only two valid fossil species for Ranina. Consequently, no fossil representatives of Ranina are reported to date from the Eastern Pacific and Atlantic areas.

- Tethyranina $\mathrm{n}$. gen. is herein proposed to accommodate $R$. propinqua from the Mediterranean area, previously assigned to Ranina.

- ?Ranina pellattieroi De Angeli \& Beschin, 2011, lacking the typical characters of Ranina, and having incomplete rostrum and peculiar dorsal ornamentation, is herein parsimoniously considered as a doubtful species within Ranininae De Hann, 1839.

- Finally, this review attests that, at our present knowledge, the fossil record of Ranina is still too scarce and poorly documented to support possible valid hypotheses in order to clarify the real origin, distribution, and relationships of the genus with the other genera within Ranininae.

\section{Acknowledgements}

We wish to thanks D. Guinot, Muséum national d'Histoire naturelle, Département Milieux et peuplements aquatiques, Paris (France) for useful discussion on systematics of the extant Ranina ranina; J. Luque, Department of Biological Sciences, University of Alberta, Edmonton (Canada) for useful discussion on systematics of the extant Ranina ranina and critical lecture and review of the manuscript; T. Nyborg, Department of Earth and Biological Sciences, Loma Linda University, Loma Linda, CA (U.S.A.) for useful discussion on the western Pacific Ranininae species and for critical review of the manuscript; D. Ormezzano, Museo Regionale di Scienze Naturali, Torino (Italy) for information on the type material of Ranina palmea.

\section{REFERENCES}

Baldanza A., Bizzarri R., Famiani F., Pasini G., Garassino A. \& De Angeli A., 2014 - Early Pleistocene shallow marine decapod crustaceans community from Fabro Scalo (western Umbria, central Italy): taxonomic inferences and palaeoenvironmental reconstruction. Neues Jahrbuch für Geologie und Paläontologie, Abhandlungen, 271 (3): 261-283. 
Bizzarri R. \& Baldanza A., 2009 - Plio-Pleistocene deltaic deposits in the Città della Pieve area (western Umbria central Italy): facies analysis and inferred relations with the South Chiana Valley fluvial deposits. Il Quaternario, 22 (2): 127-138.

Brocchi P., 1877 - Description de quelques Crustacés fossiles appartenant à la tribu des Raniniens. Annales de la Societé Géologique, 8: 1-6.

Crema C., 1895 - Sopra alcuni decapodi terziarii del Piemonte. Accademia delle Scienze di Torino, 30: 664681.

De Angeli A. \& Beschin C., 2011 - Il genere Ranina Lamarck, 1801 (Crustacea, Decapoda, Raninidae) nel Terziario del Vicentino, con descrizione di due nuove specie. Studi e Ricerche - Associazione Amici del Museo-Museo Civico "G. Zannato", 18: 11-20.

De Angeli A., Dall'Igna G.L. \& Ceccon L., 2009 - Segnalazione di Ranina sp. (Decapoda, Brachyura, Raninidae) dell'Eocene superiore di Monte Malo (Vicenza, Italia settentrionale). Lavori - Società Veneziana di Scienze Naturali, 34: 119-122.

De Angeli A. \& Garassino A., 2006 - Catalog and bibliography of fossil stomatopoda and decapoda from Italy. Memorie della Società italiana di Scienze naturali e del Museo civico di Storia naturale di Milano, 35 (1): 3-96.

De Haan H.M., 1833-1849 - Crustacea. In: Faunas Japonica, sive Descriptio animalium, quae in itinere per Japoniam, jussu et auspiciis superiorum, qui summum in India Batavia imperium tenet, suscepto, annis 18231830 collegit, notis, observationibus a adumbrationibus illustravit. Siebold, P.F. v. (ed.). J. Müller et Co., Lugduni Batavorum.

Emmerson W.D., 2016 - The Decapod of Namibia, South Africa and Mozambique. Family Raninidae De Haan, 1839. Cambridge Scholars Publishing, Vol. 2..

Fabiani R., 1910 - Sulle specie di Ranina finora note ed in particolare sulla Ranina Aldrovandii. Atti della Accademia Scientifica Veneto-Trentino-Istriana, 3 (3): 85-102.

Famiani F., Baldanza A., Bizzarri R., De Angeli A., Garassino A. \& Pasini G., 2015 - New report of Ranina propinqua Ristori, 1891 (Brachyura, Raninidae) from central Italy. Neues Jahrbuch für Geologie und Paläontologie, Abhandlungen, 275 (3): 337-346.

Garassino A., Pasini G., De Angeli A. \& Hyžný M., 2014 - The decapod fauna (Axiidea, Anomura, Brachyura) from the Late Pleistocene of Trumbacà, Reggio Calabria (Calabria, southern Italy). Natural History Sciences. Atti della Società italiana di Scienze naturali e del Museo civico di Storia naturale in Milano, 1 (2): 119-130.

Glaessner M.F., 1929 - Crustacea Decapoda. In: Fossilium Catalogus. I: Animalia. Pompeckj F.J. (ed.). $W$. Junk, Berlin, 41: 1-464.

Karasawa H., 1997 - A monograph of Cenozoic Stomatopod, Decapod, Isopod and Amphipod Crustacea from West Japan. Monograph of the Mizunami Fossil Museum, 8: 1-81.

Karasawa H., 2000 - Coral-associated decapod Crustacea from the Pliocene Daito Limestone Formation and
Pleistocene Ryukyu Group, Ryukyu Islands, Japan. Bulletin of the Mizunami Fossil Museum, 27: 167189.

Karasawa H., Schweitzer C.E., Feldmann R.M. \& Luque J., 2014 - Phylogeny and classification of Raninoida (Decapoda: Brachyura). Journal of Crustacean Biology, 34 (2): 216-272.

Lamarck J.B.P.A. de Monet de, 1801 - Systéme des animaux sans vertèbres, ou Tableau general des classes, des ordres et des genres de ces animaux; Présentant leurs caractères essentiels et leur distribution, d'après la considération de leurs rapports naturels et de leur organisation, et suivant l'arrangement établi dans les galeries du Muséum d'Hist. Naturelle, parmi leurs dépouilles conservées; Précédé du discours d'ouverture du Cours de Zoologie donné dans le Muséum National d'Histoire Naturelle l'an 8 de la République.

Latreille P.A., 1810 - Considérations générales sur l'Ordre naturel des Animaux composant les Classes des Crustacés, des Arachnides et des Insectes; avec un tableau Méthodique de leurs genres, disposés en familles.

Linnaeus C., 1758 - Systema Naturae per Regna Tria Naturae, Secundum Classes, Ordines, Genera, Species, cum Characteribus, Differentiis, Synonymis, Locis. Edition 10. 1.

Lőrenthey E., 1898 - Über die Brachyuren der palaeontologischen sammlung des Bayrischen Staates. Természetrajzi Füzetek, 21: 134-152.

Lörenthey E. \& Beurlen K., 1929 - Die Fossilen Dekapoden der Länder der Ungarischen Krone. Geologica Hungarica (Palaeontologica), 3: 1-421.

Manni R., 2006 - Catalogue of the type fossils stored in the Palaeontological Museum of "La Sapienza" of Rome. Geologica Romana, 39: 95-110.

Matondo Dulce-Amor P. \& Demayo C.G., 2015 - Morphological description of the red frog crab $R$. ranina Linnaeus, 1758 (Brachyura: Raninidae) from South Western Mindanao, Philippines. Journal of Entomology and Zoology Studies, 3 (2): 251-256.

Milne Edwards A., 1872 - Note sur quelques Crustacés fossiles appartenant aux genres Ranina et Galenopsis. Annales des Sciences Géologiques, 3: 1-11.

Minagawa M., 1993 - Relative growth and sexual dimorphism in the red frog crab Ranina ranina (Decapoda: Raninidae). Nippon Suisan Gakkaishi, 59: 20252030.

Münster G. Graf zu, 1840 - Über ein neues Brachyurengenus in den tertiären Formationen des nordwestlichen Deutschlands. Beiträge zur Petrefactenkunde, 3: 23-25.

Oshiro I. \& Sakida S., 1980 - A fossil Ranina discovered from the Ryukyu Limestone. Bulletin Okinawa Prefecture Museum, 6: 1-8. (In Japanese).

Pasini G. \& Garassino A., 2010 - New report of Dardanus substriatus (A. Milne-Edwards, 1861) (Anomura, Paguroidea, Diogenidae) from the Early Pliocene of Ficulle, Terni (Umbria, Central Italy). Atti della Società italiana di Scienze naturali e del Museo civico di Storia naturale in Milano, 151 (1): 113-116. 
Pasini G. \& Garassino A., 2015 - Ranina sp. (Brachyura, Raninidae) from the Pliocene sands of "Serre di Rapolano" (Siena, Tuscany, central Italy). Natural History Sciences. Atti della Società italiana di Scienze naturali e del Museo civico di Storia naturale in Milano, 2 (1): 50-52.

Pasini G. \& Garassino A., 2017a - A preliminary review of the fossil species of Ranina Lamarck, 1801 (Decapoda, Brachyura, Raninidae) with systematic remarks. Natural History Sciences. Atti della Società italiana di Scienze naturali e del Museo civico di Storia naturale in Milano, 4 (1): 43-72.

Pasini G. \& Garassino A., 2017b - A new raninid crab (Decapoda, Brachyura, Raninidae) from the early Oligocene (late Rupelian) of Italy: systematics and palaeogeographic evidences. Natural History Sciences. Atti della Società italiana di Scienze naturali e del Museo civico di Storia naturale in Milano, 4 (1): $87-$ 96.

Poore G.C.B., 2004 - Marine Decapoda Crustacea of Southern Australia. A Guide to Identification. CSIRO Pubbl., Melbourne.

Reuss A.E., 1859 - Zur Kenntnis fossiler Krabben. Akademie der Wissenschaften Wien, Denkschrift, 17: 1-90.

Ristori G., 1891 - Contributo alla fauna carcinologica del Pliocene Italiano. Atti della Società Toscana di Scienze Naturali, 11: 3-18.

Sakai T., 1937 - Studies on the Crabs of Japan. II Oxystomata. Reports of the Tokyo Bunrika Daigaku, Section B, 2: 178-180.

Schweitzer C.E., 2003 - Utility of proxy characters for classification of fossils: an example from the fossil Xanthoidea (Crustacea: Decapoda: Brachyura). Journal of Paleontology, 77 (6): 1107-1128.

Schweitzer C.E, Feldmann R.M., Garassino A., Karasawa H. \& Schweigert G., 2010 - Systematic list of fossil decapod crustacean species. Crustaceana Monographs, 10.

Sismonda E., 1846 - Descrizione dei pesci e dei crostacei fossili nel Piemonte. Memorie della Reale Accademia di Scienze di Torino, 10 (2): 1-89.

Uchida R., 1986 - Raninoidae kona crab. In: NOAA Technical Report NMFS 38. Uchida R. \& Uchiyama J. (eds.). Fishery Atlas of the northwestern Hawaiian Islands: $70-71$.

Van Bakel W.M., Guinot D., Artal P., Fraaije R.H.B. \& Jagt J.W.M., 2012 - A revision of the Palaeocorystoidea and the phylogeny of raninoidian crabs (Crustacea, Decapoda, Brachyura, Podotremata). Zootaxa, 3215: 1-216. 